\title{
The impact of HTLV-1 infection on clinical and immunological outcomes in patients coinfected with HIV and hepatitis $C$ virus
}

\author{
Fabianna Bahia ${ }^{1 *}$, Chloe Le Marchand ${ }^{2}$, Jennifer Evans ${ }^{2}$, Eduardo Netto ${ }^{1}$, Kimberly Page ${ }^{2}$, Carlos Brites ${ }^{1}$ \\ From 15th International Conference on Human Retroviruses: HTLV and Related Viruses \\ Leuven and Gembloux, Belgium. 5-8 June 2011
}

\section{Introduction}

HIV, hepatitis C (HCV), and human T-cell lymphotropic virus I (HTLV-1) are associated with high global burdens of disease, notably in resource-poor locales. They share similar routes of transmission and cause chronic infections with associated morbidity. We performed a cross-sectional study to assess the impact of HTLV-1 infection on clinical outcomes in $\mathrm{HIV} / \mathrm{HCV}$ co-infected patients.

\section{Methods}

We enrolled 102 (72.3\%) with HIV/HCV co-infection (Group 1) and 39 (27.7\%) triply infected with HIV, HCV, and HTLV-1 (Group 2). We reviewed medical records of two groups of patients followed in two outpatients services in Salvador, Brazil. We collected and compared demographic, behavioral-related information, immunological, virological and histological parameters for HIV-1 and HCV infection.

\section{Results}

Demographics, virological and immunological characteristics were similar in the two groups; a higher proportion of triply infected patients (Group 2) reported any history of injection drug use (IDU) compared to dually infected (Group 1) patients ( $75 \%$ vs. $45.8 \%$; p $=0.003$ ). No differences were seen between groups in HIV clinical outcomes (CD4 count and viral load). Alanine aminotransferase levels were significantly higher in HIV/ HCV co-infected patients $(\mathrm{p}=0.045)$. Liver fibrosis damage based on Metavir scores were similar between

* Correspondence: fabianna.bahia@gmail.com

${ }^{1}$ Federal University of Bahia, Bahia, Brazil

Full list of author information is available at the end of the article groups (0.97) but were worse with lower CD4 cell count (under 200cells $/ \mathrm{mm} 3)(\mathrm{p}=0.01)$.

\section{Conclusions}

HIV/HTLV-1 and HIV/HCV coinfections may worsen clinical related outcomes, but virological and immunological outcomes were similar in both groups. Hepatic measures were worse in patients with more severe immunosuppression.

\section{Author details}

${ }^{1}$ Federal University of Bahia, Bahia, Brazil. ${ }^{2}$ University of California, San Franscisco, CA, USA.

Published: 6 June 2011

doi:10.1186/1742-4690-8-S1-A54

Cite this article as: Bahia et al:: The impact of HTLV-1 infection on clinical and immunological outcomes in patients coinfected with HIV and hepatitis C virus. Retrovirology 2011 8(Suppl 1):A54.

Submit your next manuscript to BioMed Central and take full advantage of:

- Convenient online submission

- Thorough peer review

- No space constraints or color figure charges

- Immediate publication on acceptance

- Inclusion in PubMed, CAS, Scopus and Google Scholar

- Research which is freely available for redistribution

Submit your manuscript at www.biomedcentral.com/submit 